\title{
HILGARDIA
}

A Journal of Agricultural Science Published by the California Agricultural Experiment Station

\section{THE DEVELOPMENT OF AN INSECT VIRUS WITHIN CELLS OF ITS HOST} KENNETH M. HUGHES 
Stages in the development of an insect virus are shown in this study. Ultra-thin sections of diseased tissue were observed and photographed with the electron microscope. The presence of virus particles in large numbers in the infected cell nucleus is demonstrated by electron micrographs. Information on the development of polyhedral bodies is presented. 


\title{
H I L G A R D I A
}

A Journal of Agricultural Science Published by

the California Agricultural Experiment Station

\section{THE DEVELOPMENT OF AN INSECT VIRUS WITHIN CELLS OF ITS HOST ${ }^{1}$}

\author{
KENNETH M. HUGHES
}

\section{INTRODUCTION}

Although the polyhedral virus diseases of insects have been known and studied for many years, present knowledge of the morphology and development of the virus may be dated from the demonstration of the particles by Bergold in 1947. He showed that the microscopically visible polyhedral bodies are composed principally of noninfectious protein material within which infectious rod-shaped particles are embedded.

Since that time, numerous studies by different scientists have contributed to knowledge of the nature of these virus particles. Most of the recent observations have been based on material which could be considered the endproduct of the infectious proeess-virus particles liberated by the dissolution of polyhedral bodies which have been extracted from dead or dying insects.

Using material derived in this way, Bergold (1950) demonstrated evidence of a developmental cycle of the virus particles. Though his observations were made on particles taken from insects in an advanced stage of disease, his belief that he could show stages in the development of the virus particles was based on the reasoning that virus particles at different stages of development would be present in any one infected cell; that polyhedral bodies form rapidly, occluding particles in various stages of development; and that the fully formed polyhedron would thus contain virus particles caught and held at various stages of development. Bird (1952) used a different approach to the problem of virus development. He made thin sections of diseased tissue at a rather early stage of infection in an attempt to show stages of virus development and succeeded in demonstrating only a few virus particles within the host cells.

The present paper reports the results of a similar study based on the electron microscope examination of thin sections of virus-diseased tissue.

\footnotetext{
${ }^{1}$ Contribution from the Laboratory of Insect Pathology, Department of Biological Control, College of Agriculture, University of California, Berkeley.

${ }^{2}$ Assistant Specialist in the Experiment Station, Berkeley.
} 


\section{MATERIALS AND METHODS}

The virus used for this study was Borrelina campeoles Steinhaus, a polyhedrosis virus affecting the alfalfa caterpillar, Colias philodice eurytheme Bdvl. The disease and its causative virus have been described by Steinhaus $(1948 ; 1949 a, b)$.

The insects were infected by feeding them alfalfa dipped in a suspension of polyhedra. At various intervals after infection, specimens were dissected and bits of fat tissue were removed and fixed in one per cent osmium tetroxide buffered at $\mathrm{pH}$ 7.0. The fixed tissue was dehydrated and embedded in butyl methacrylate by the method of Newman, Borysko, and Swerdlow (1949). Sectioning was done on a Spencer microtome modified in the manner described by Pease and Baker (1948). Sections were cut at a setting of 0.1 micron. The methacrylate matrix was removed from the sections in amyl acetate; the sections were then embedded in a film of collodion for examination. No metallic shadowing was used.

The microscope used was an RCA EMU-2. The recently developed wide field pole piece was not available to the author at the time these observations were being made. Consequently, all of the illustrations presented here were made with the normal objective pole piece.

\section{RESULTS}

Preliminary Observations. Virus-diseased alfalfa caterpillars usually die within five to ten days after infection. Although sections were made at various intervals after infection, the most information was obtained from tissue taken during a rather narrow interval of time approximately midway between infection and mortality. A common observation with the light microscope is that infection does not progress simultaneously in all cells of a tissue. Thus, at a midpoint in the course of infection, only a few cells scattered throughout a piece of tissue may be seen to have small polyhedra in the nuclei, whereas somewhat later nearly every cell will be seen to contain polyhedra. Similarly, it was found in the present study that fat tissue fixed at three and a half days after infection produced sections in which cells in various stages of infection could be seen.

In this one group of sections it was possible to see nuclei in which no virus was visible, ones that were filled with virus particles, and others that contained fairly well-developed polyhedra. Sections made only slightly earlier in the course of infection revealed many nuclei that were obviously abnormal but very few that contained recognizable virus particles. Tissue fixed one day later than the optimum time contained cells nearly all of which had readily recognizable polyhedra in the nuclei. The time intervals stated here would undoubtedly vary with the conditions under which the infected insects were maintained.

Earlier Stages of Infection. The earliest recognized pathology was represented by nuclei that were enlarged and in which the chromatin had coagulated in several irregular dense bodies (fig. 1). Outside these dense areas the nuclear material appeared as a homogeneous, finely granular matrix. No recognizable virus particles could be distinguished at this stage. 
At a slightly later stage, the chromatin becomes arranged in a central position with a clearer peripheral area surrounding it (fig. 2). The chromatin usually appears as a loose network. In occasional cells the chromatin mass may be seen occupying a position at one side of the nucleus rather than being centrally located. The appearance of this chromatin mass is well known to those who have observed polyhedrosis-diseased tissue with a light microseope. Many descriptions of it have been published since it was first noted by Breindl and Komárek (1923). A few rod-shaped virus particles may be seen in the nucleus at this stage (figures 3 and 4 ). There is some evidence that the virus particles occur primarily in the central portion of the nucleus at this early stage in their formation, possibly indicating that their formation may be related in some way to the chromatin remains.

More Advanced Stage. Figure 5 shows a nucleus in a more advanced stage of infection. The central chromatin mass occupies a smaller portion of the nucleus while the peripheral region is crowded with a multitude of virus particles. Many of the latter can be seen in bundles of two or more elements (fig. 6). Polyhedra are not yet visible at this stage. Although the virus particles are more readily detected in the peripheral region of the nucleus, they may also be seen in the central chromatin mass. Here, however, they appear to occur only as single rods. Some of the bundles in the peripheral area are surrounded by what looks like a membrane (fig. 7 ).

What may be the mechanism of bundle formation is not clarified by the present study. There is some evidence that individual virus rods may aggregate in a side-by-side fashion. This, however, could easily be a phenomenon entirely distinct from that of bundle formation. If one accounted for bundle formation on this basis alone one would also have to account for the formation of a membrane around the entire group of rods. These units-bundles of virus rods with membranes, if such they are-increase in apparent density as the infection progresses. Figure 8 shows some of these structures appearing as completely opaque ovoid bodies while in others a small amount of internal detail can still be distinguished; still others resemble those in figure 7 .

Formation of the Polyhedra. As the infective process continues, readily visible opaque structures may be seen in the peripheral zone of the nucleus (figures 9 and 11). Since one can distinguish all gradations from the small opaque bodies of figure 9 to the unquestionable polyhedra of figure 16, one cannot escape the conclusion that the small opaque structures are early polyhedra. When these are examined at higher magnification (fig. 10), they are found to be the same ovoid bodies noted in the preceding paragraph, or, more often, several such bodies in close association. As the developing polyhedra become larger they appear to be composed of a larger number of ovoid units which are becoming fused in a single opaque mass (fig. 12).

Thus it appears to the writer that polyhedral bodies start as bundles of virus particles enclosed in globular membranes. An elaboration or deposition of some dense material within these membranes results in the whole structure becoming opaque to the electron beam. Then, as several of these units occur in close proximity, a further deposition of dense material around and between them embeds a number of them in one mass. Successive layers of the 
polyhedral protein incorporate into the same mass more of the bundles lying at the periphery of the "growing" polyhedron. Small polyhedra have an irregular, "knobby" appearance expected of a structure made up of several ovoid bodies (figures 12, 13, and 14).

This concept of the manner in which polyhedra develop might seem to be complicated by the fact that polyhedra have been observed to have a limiting membrane. There appears to be no reason to believe, however, that this membrane is anything more than the surface portion of polyhedral protein which has become somewhat less soluble in alkaline solutions.

Figures 15 and 16 represent nuclei in an advanced stage of infection. The polyhedra are well developed and can readily be identified with those seen in sections with a light microscope. For comparable light micrographs of sections of infected cells of the same host, the reader is referred to those presented by Steinhaus (1949b; see figure 153).

Although they may not be distinguishable in the reproduction presented here, the original print used for figure 15 showed numerous virus particles in the central mass. For the most part these appeared to be individual rods. What the eventual fate of these particles might be is not clear. It is quite possible that they become incorporated into polyhedra as the latter fill the center of the nucleus. Although this seems to take place frequently, it is not unusual to find, in the tissues of an insect that has died of the disease, cells with polyhedra occupying the peripheral portions of the nucleus and surrounding a polyhedra-free central portion.

\section{DISCUSSION}

Early Work of Paillot. An adequate treatment of the subject presented here necessitates consideration of some of the findings of previous investigators in light of the results of the present work. In 1924 Paillot, using a darkfield microscope, studied the blood cells of the silkworm during the intermediate stages of infection by a polyhedrosis virus. He described a peripheral zone of the infected nucleus in which he could see small bright particles. Reference to figure 5 will make it fairly evident what Paillot was describing.

Whether individual virus particles could have been detected by Paillot with his dark-field microscope seems questionable. However, the bundles appearing in the peripheral zone are rather prominent structures which could have been demonstrated readily with Paillot's equipment. By studying similar virus material with both dark-field microscope and electron microscope, Hughes (1950) previously demonstrated the identity of certain bright particles visible in the field of the former instrument with virus bundles as demonstrated with the latter one.

Relationship to Bird's Work. The work of Bird (1952) is a little difficult to correlate with the present study. He used methods similar, in part, to those described here but reached somewhat different'conclusions. The fact that he was unable to demonstrate virus particles in any considerable number in the nuclei of cells apparently can be attributed to concentration of his attention on a stage of infection not quite advanced enough for the observance of this phenomenon. This is indicated in statements in his paper and was later confirmed in conversations with the writer. On the occasion of these con- 


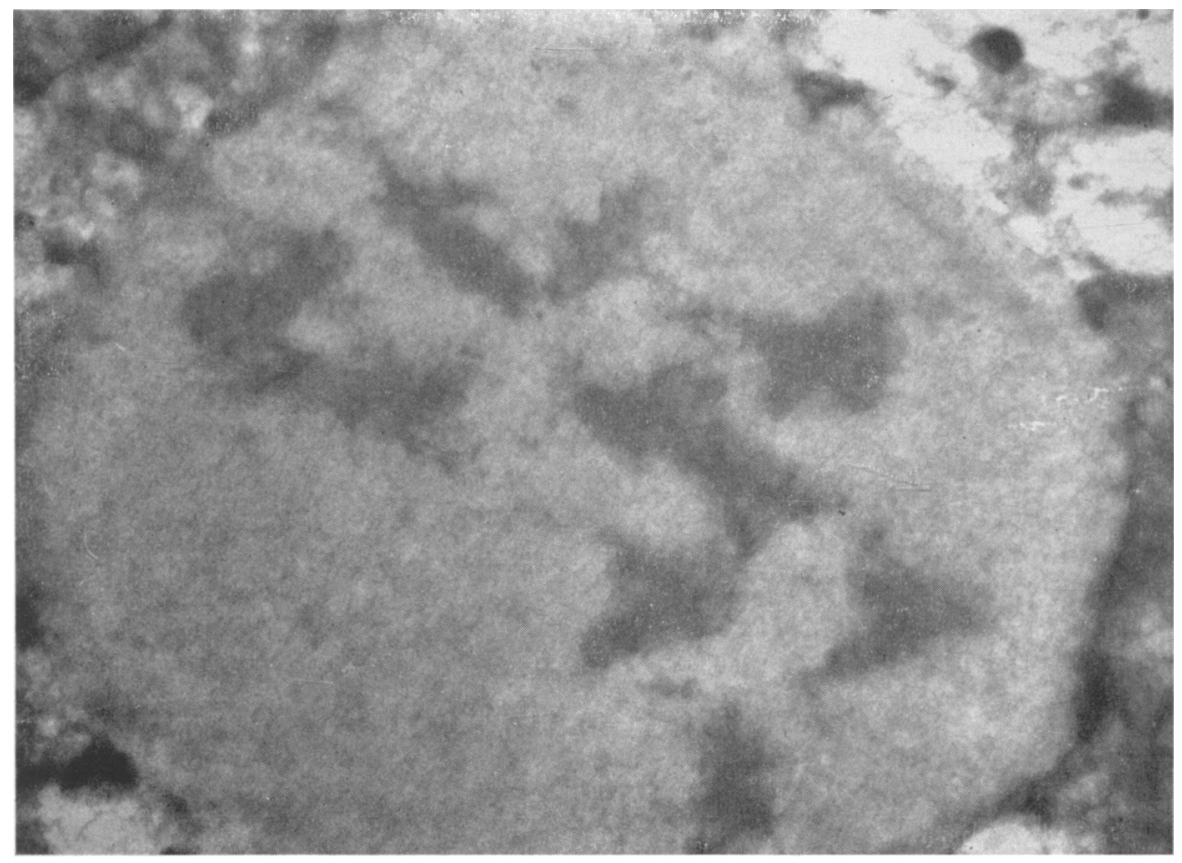

Fig. 1. Nucleus of cell at an early stage of infection. No virus particles are visible at this stage. Magnification $11,000 \times$

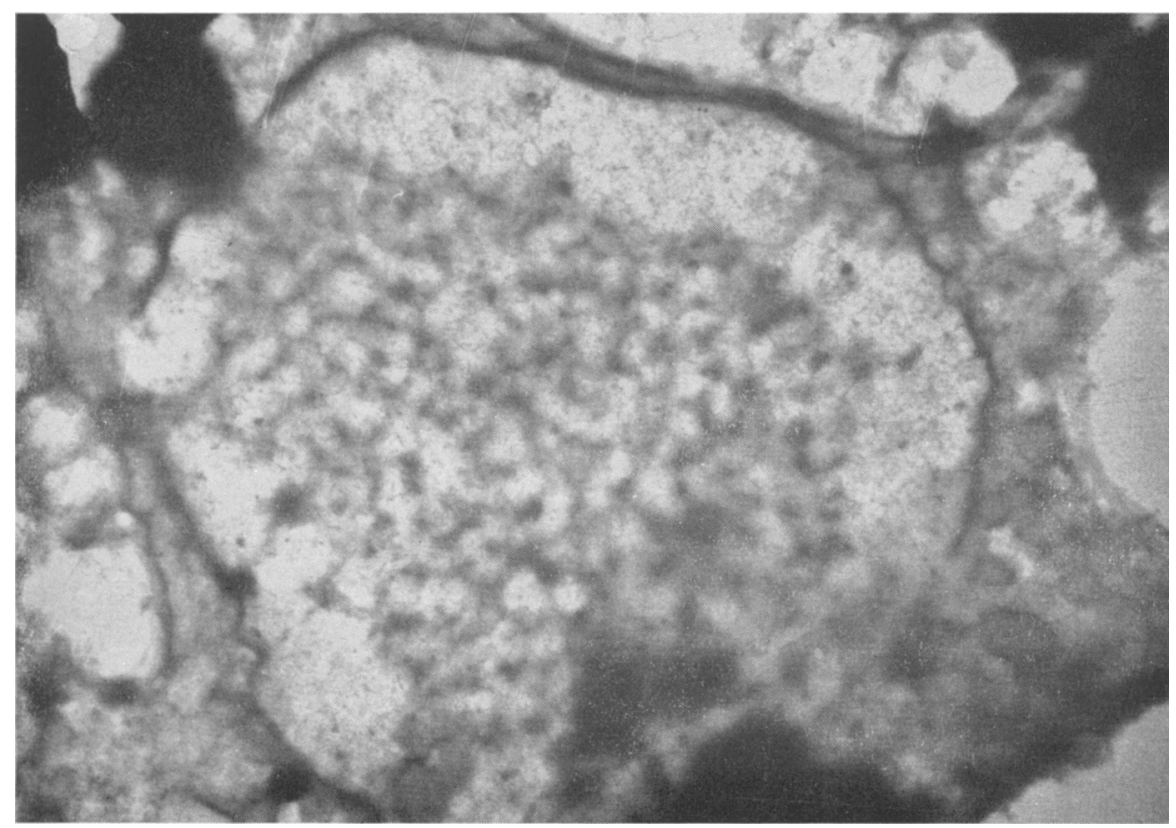

Fig. 2. Nucleus at a slightly later stage of infection. Magnification $7,000 \times$ 


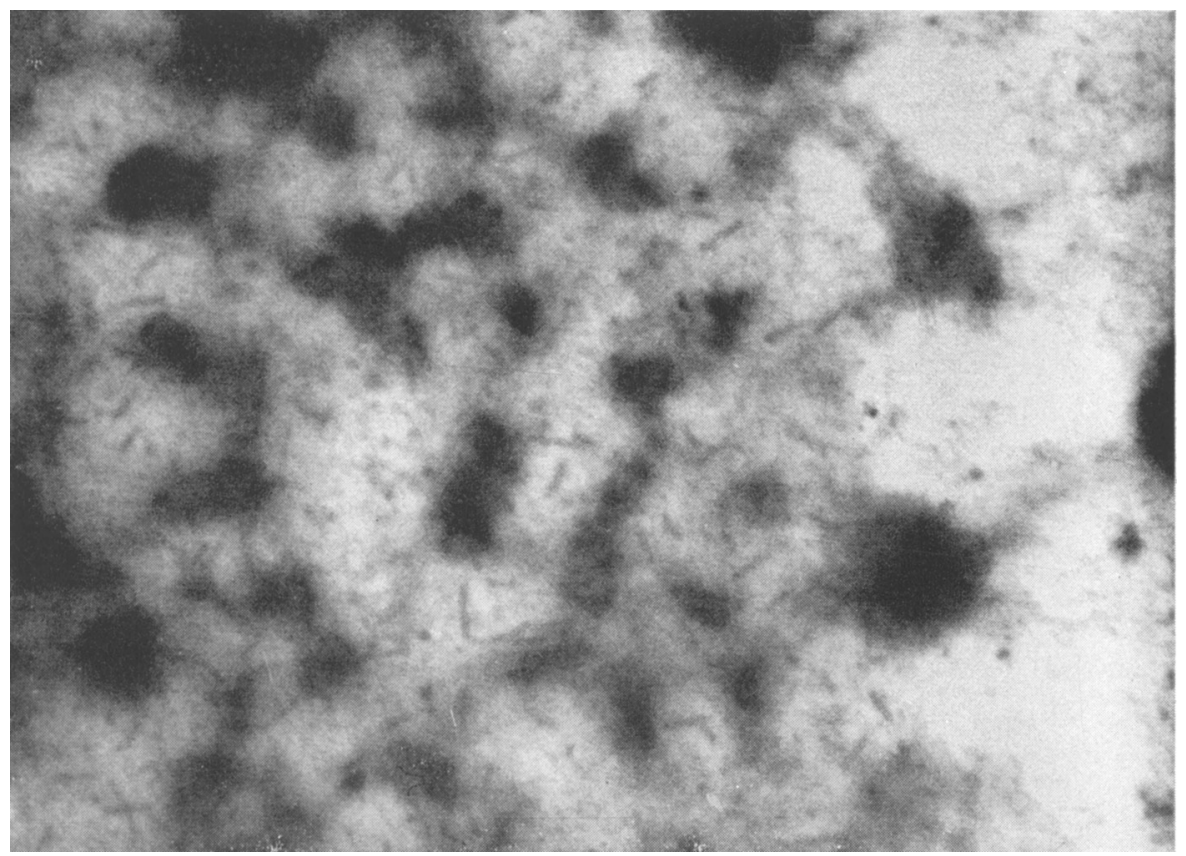

Fig. 3. Higher magnification of a portion of the nucleus shown in Fig. 2. Some virus particles are visible. Magnification 25,000 $\times$

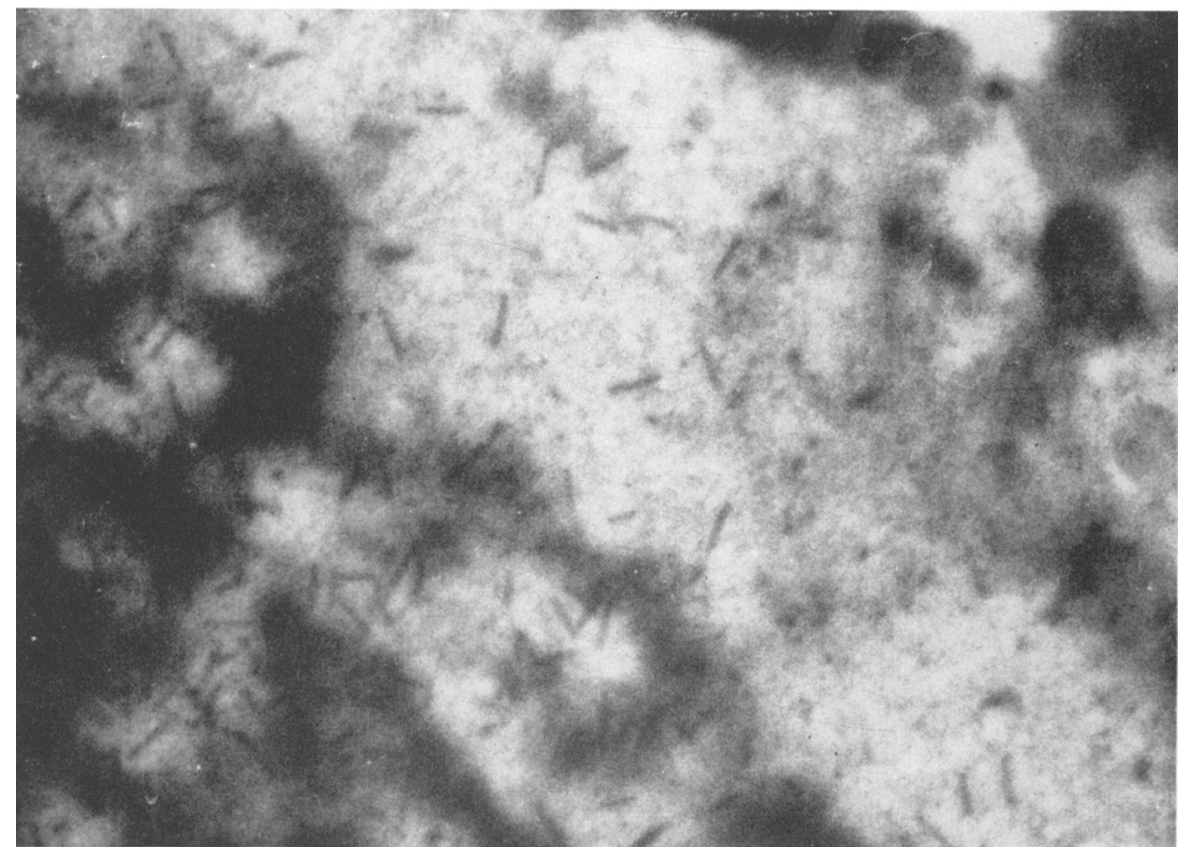

Fig. 4. Portion of a nucleus in a slightly more adranced stage of infection than that shown in Fig. 3. Magnification $25,000 \times$ 


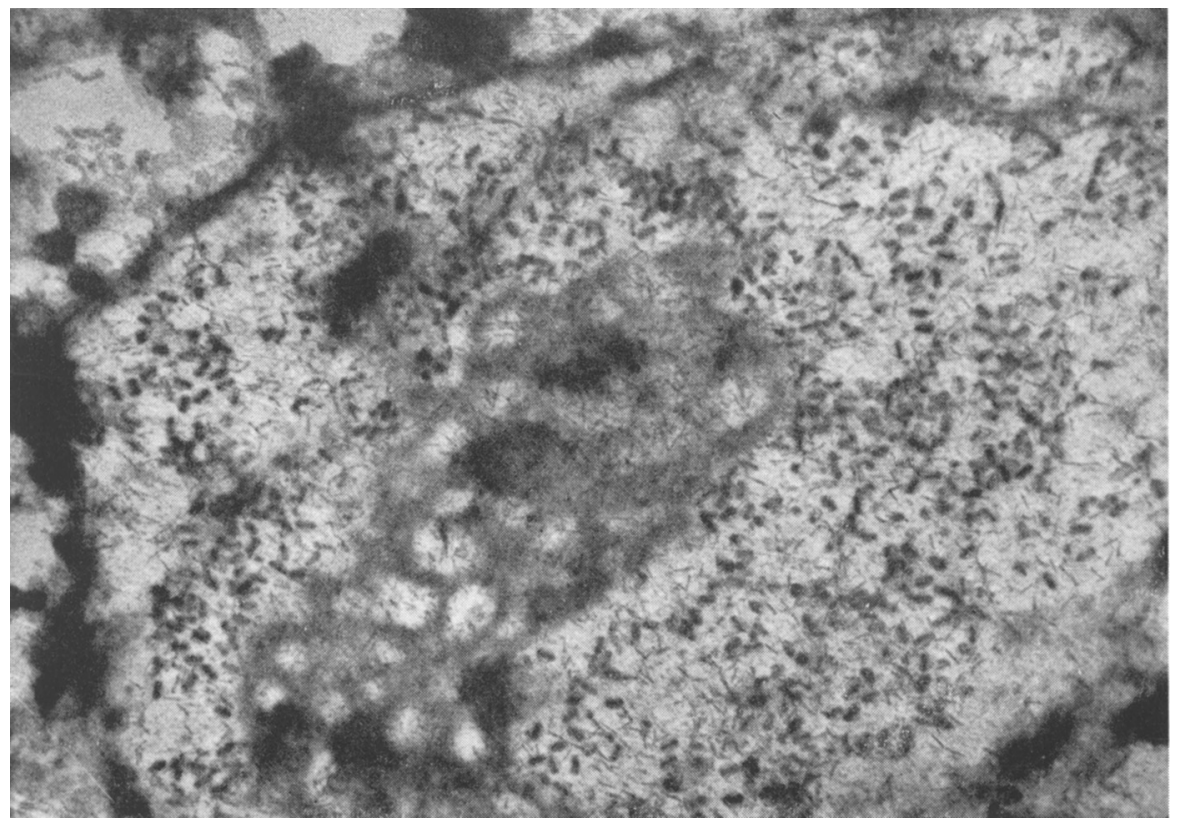

Fig. 5. Nucleus in an intermediate stage of infection. Individual virus particles and bundles are numerous. Magnification $7,000 \times$

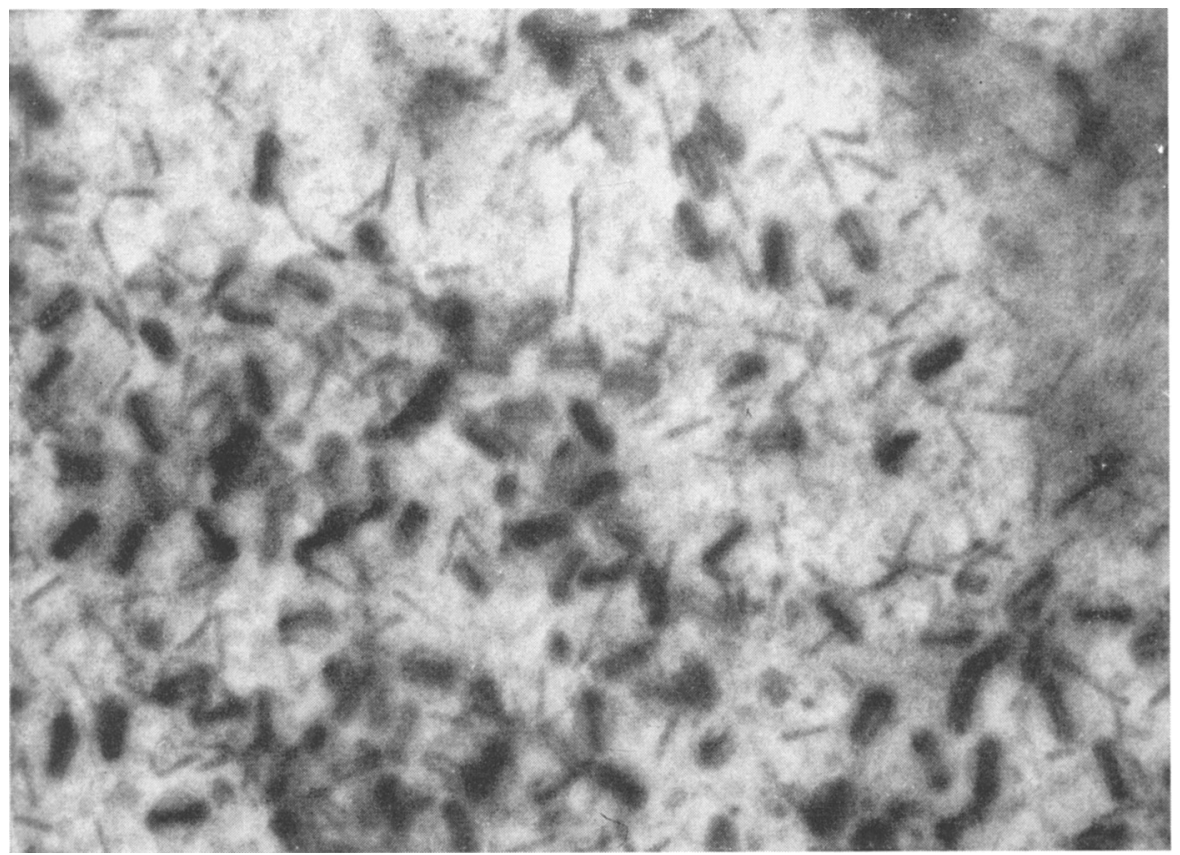

Fig. 6. Higher magnification of a portion of the nucleus shown in Fig. 5. Magnification 25,000 $\times$ 


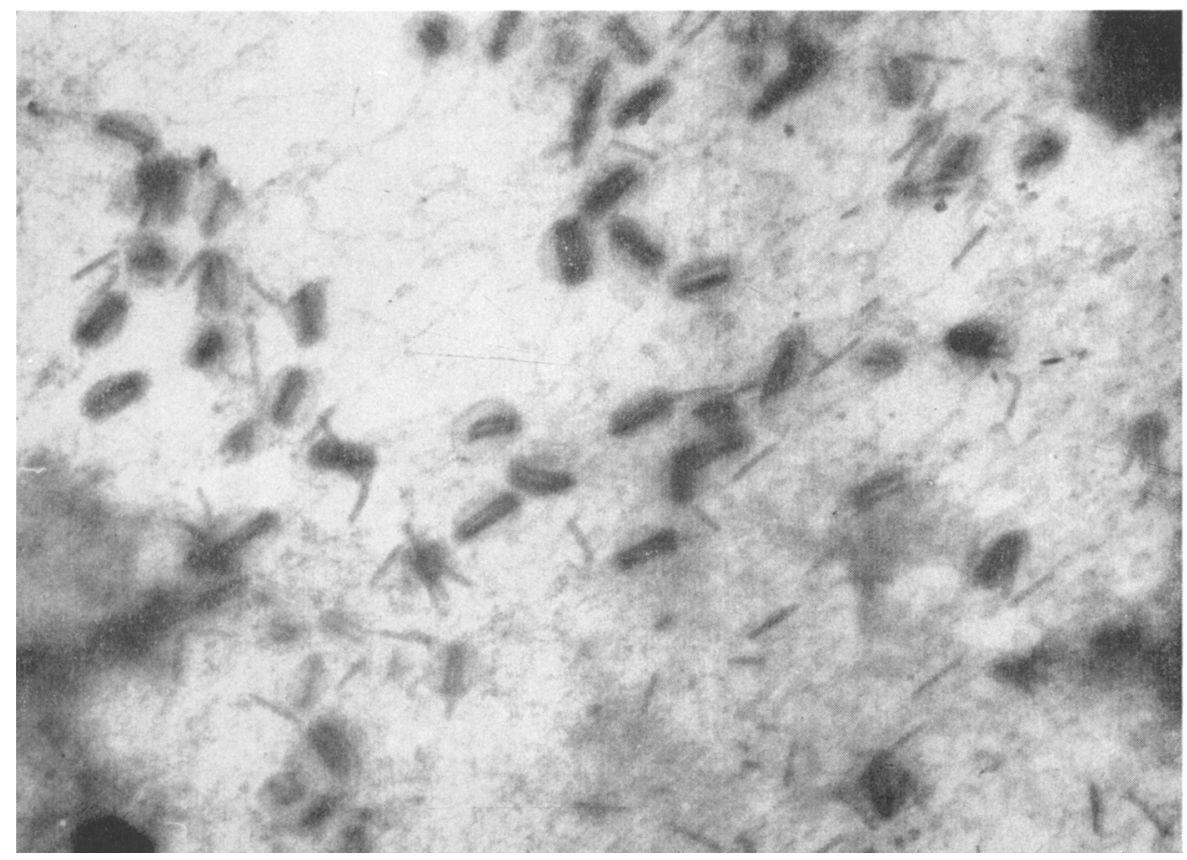

Fig. 7. Portion of a nucleus similar to that shown in Fig. 6. Bundles of virus particles appear to be surrounded by membranes. Magnification $25,000 \times$

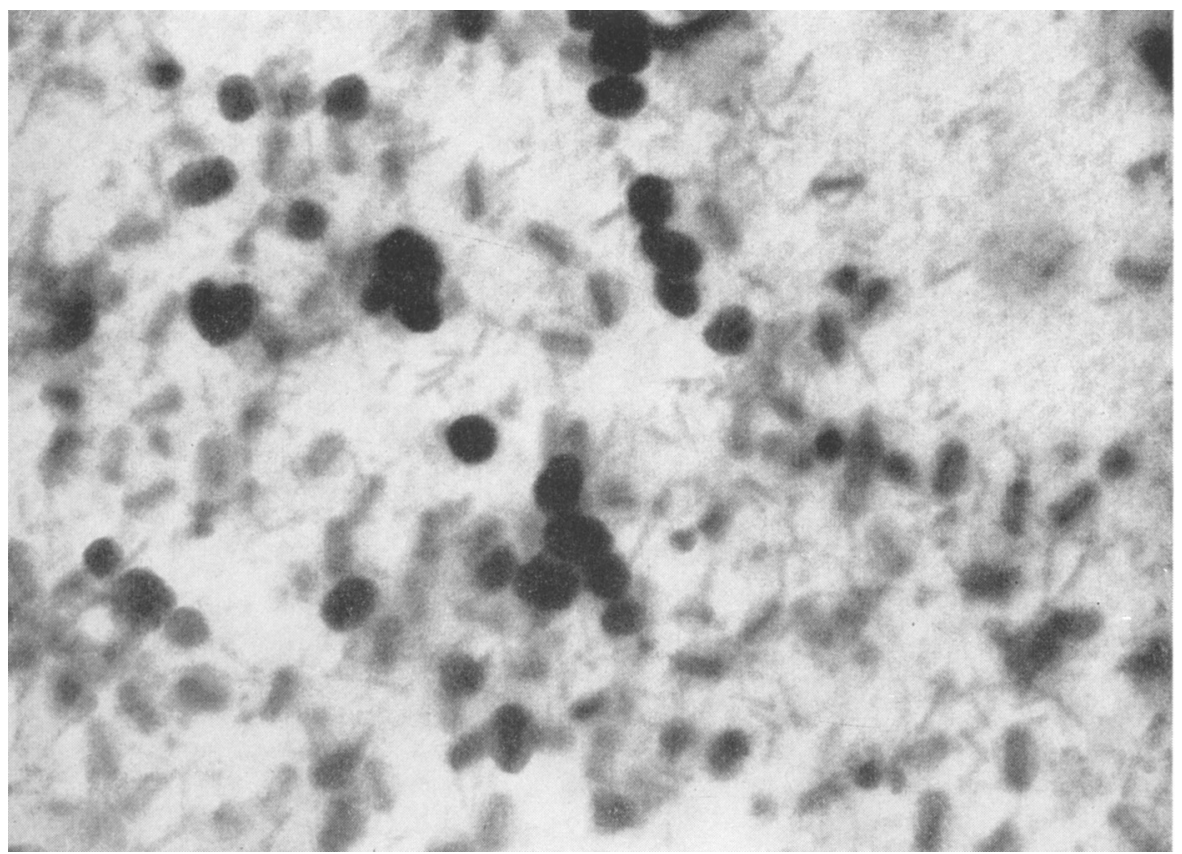

Fig. 8. Bundle-and-membrane units becoming opaque to the electron beam. Magnification 25,000 $\times$ 


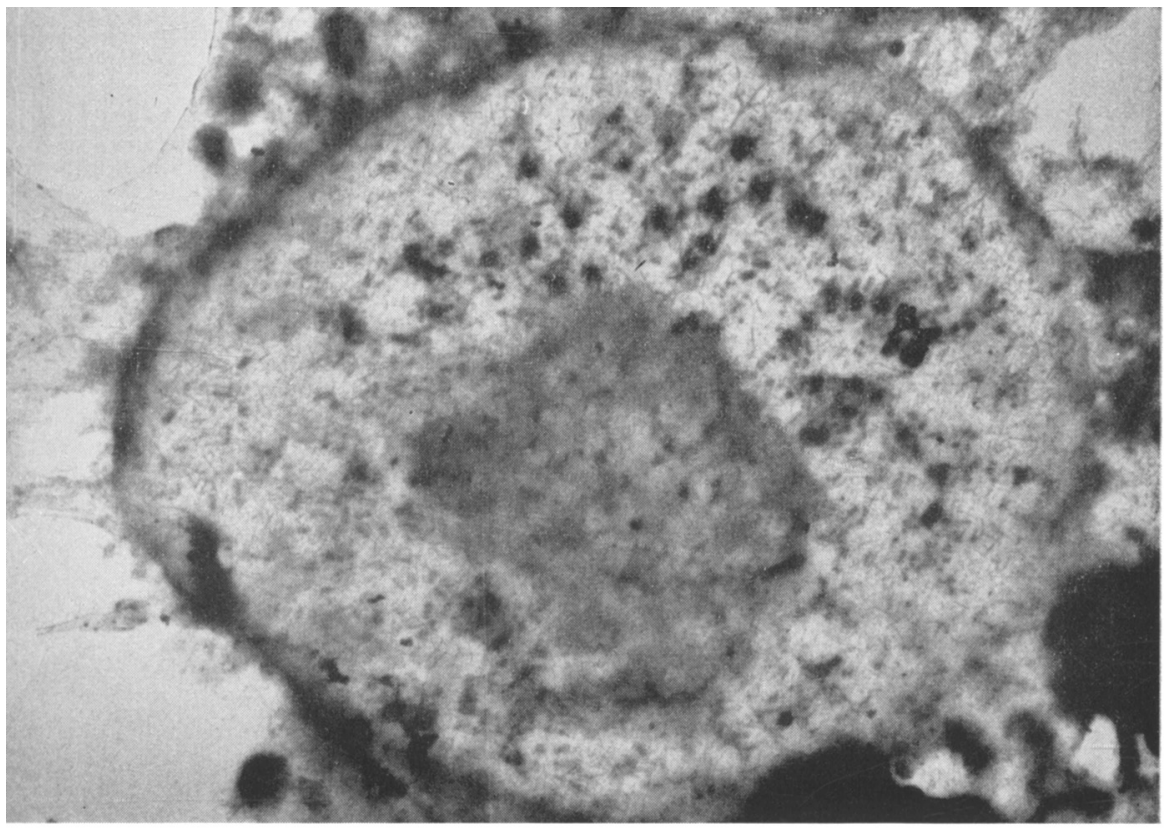

Fig. 9. Nucleus showing dense points in the peripheral zone in which polyhedra are known to form. Magnification $7,000 \times$

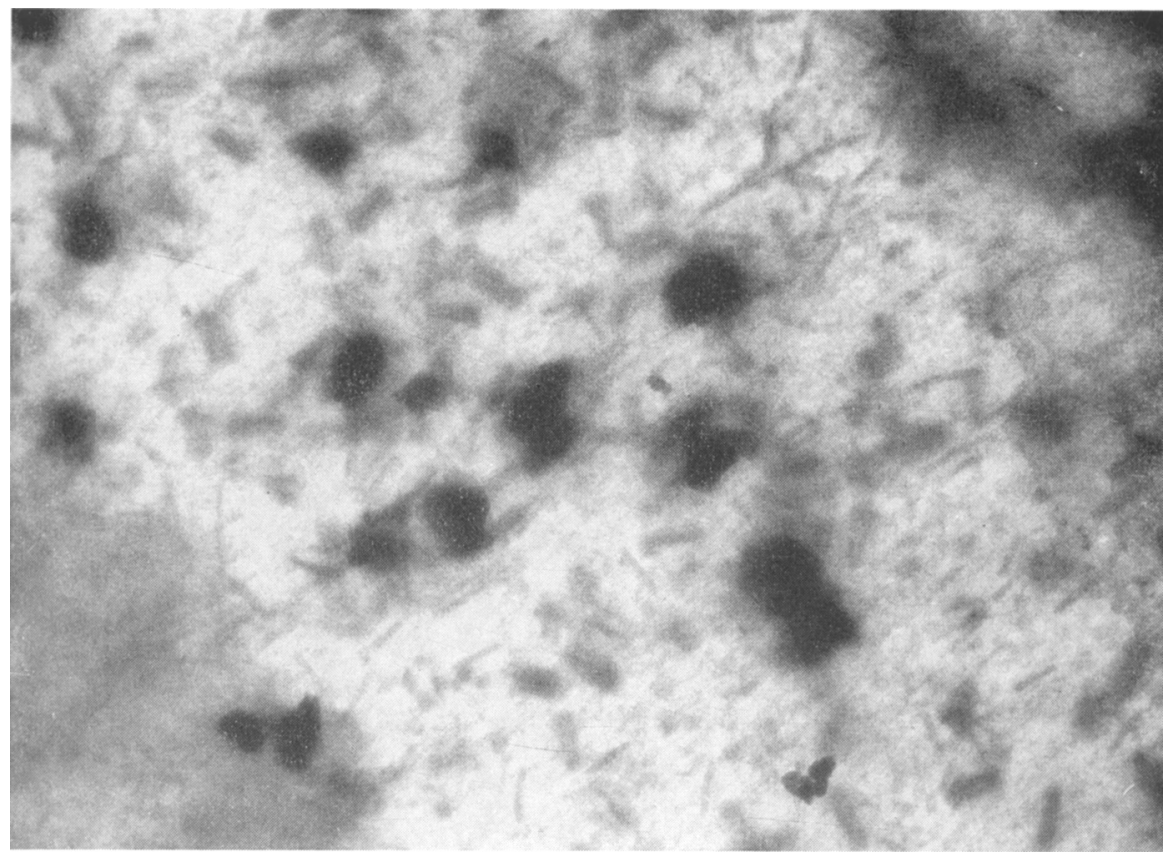

Fig. 10. Higher magnification of a portion of the nucleus shown in Fig. 9. The dense structures appear to be made up of the same units shown in Fig. 8. Magnification 25,000 $\times$ 


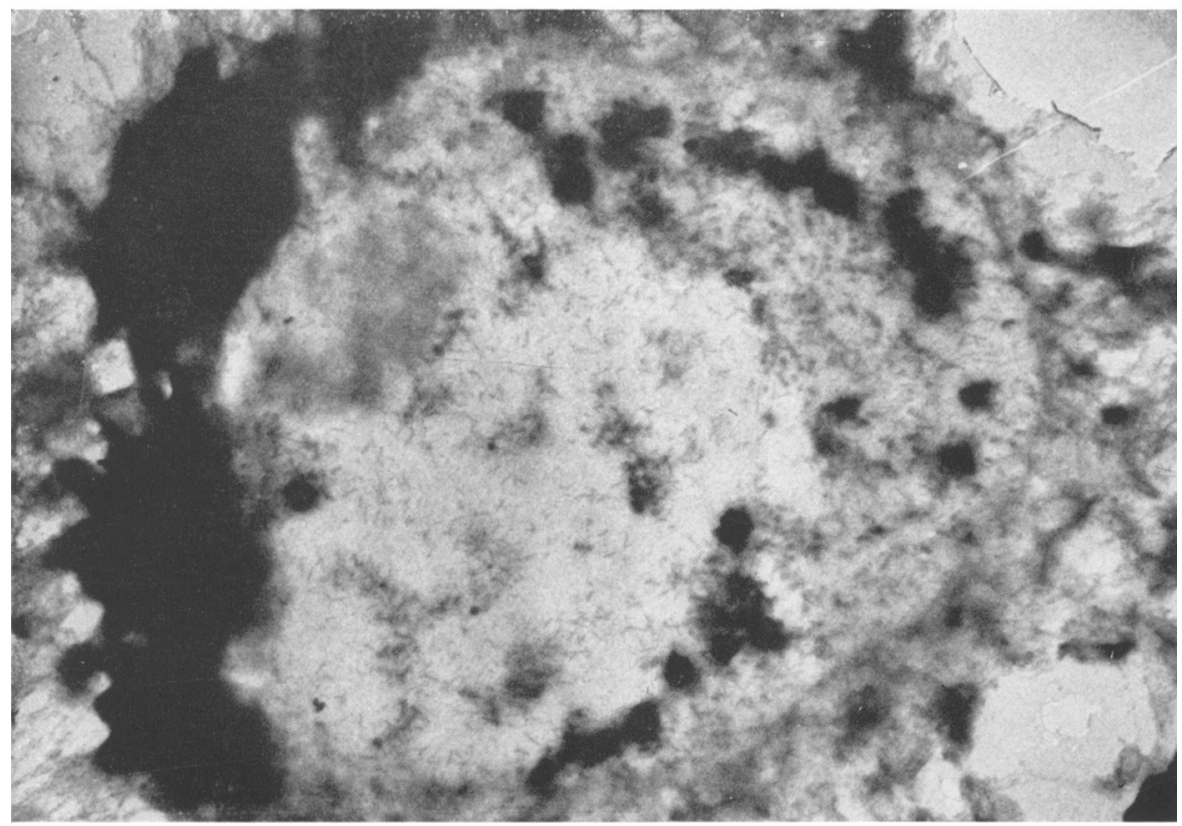

Fig. 11. Nucleus showing small but distinet polyhedra. Magnification $7,000 \times$

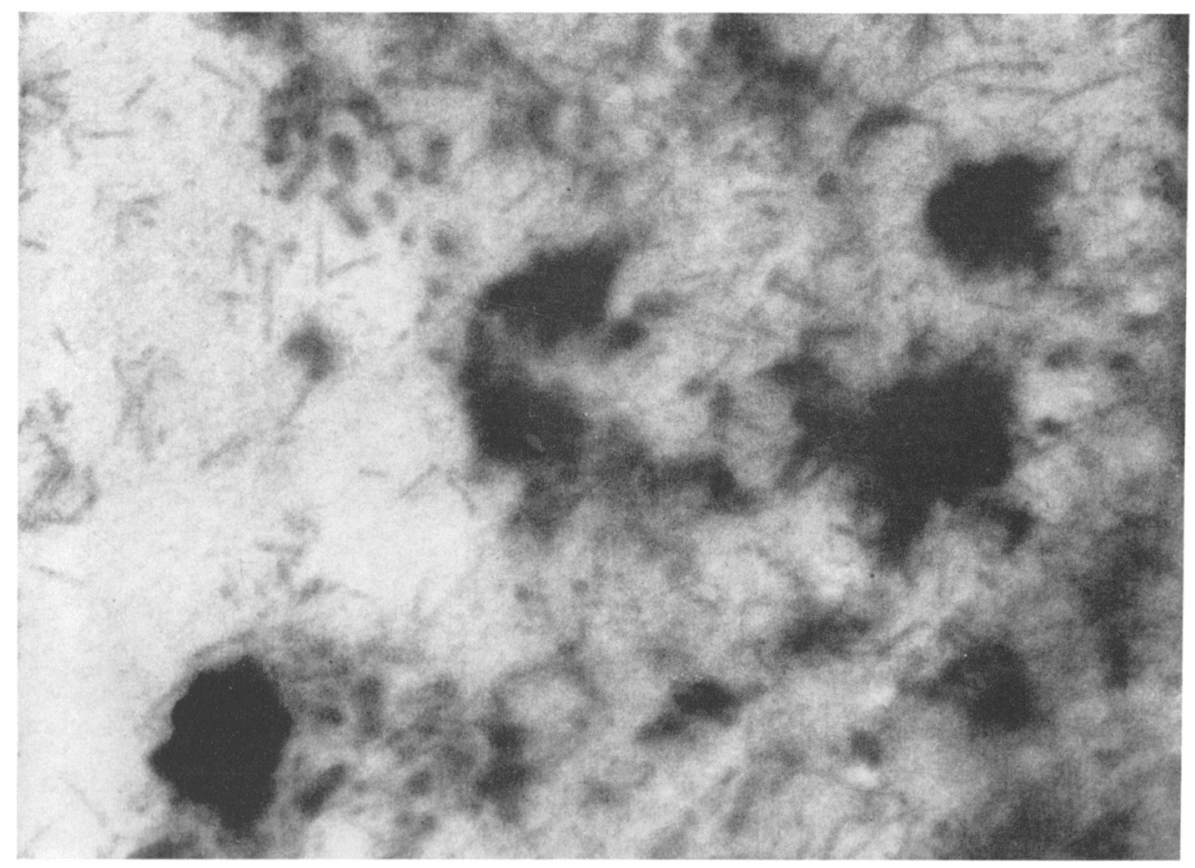

Fig. 12. Higher magnification of a portion of the nucleus shown in Fig. 11. Magnification $25,000 \times$ 


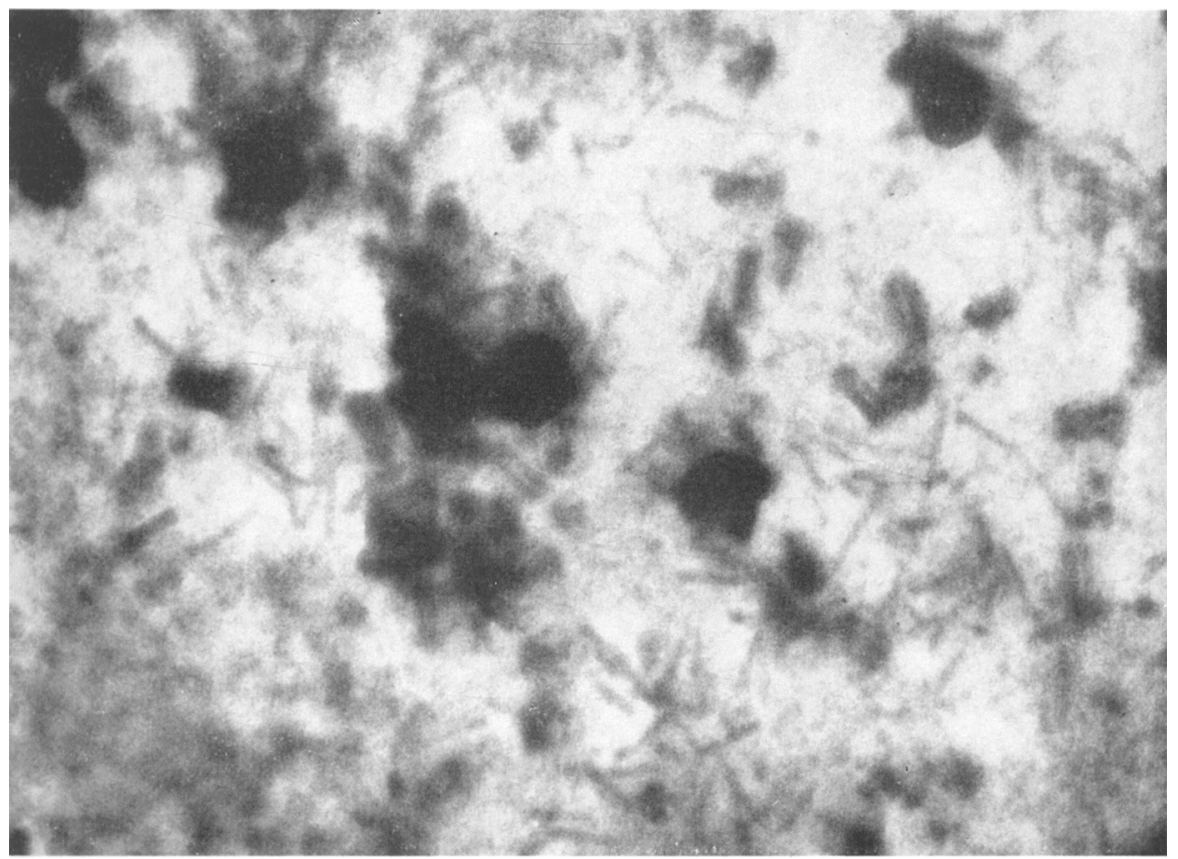

Fig. 13. Small polyhedra similar to those shown in Fig. 12. Magnification 32,000 $\times$

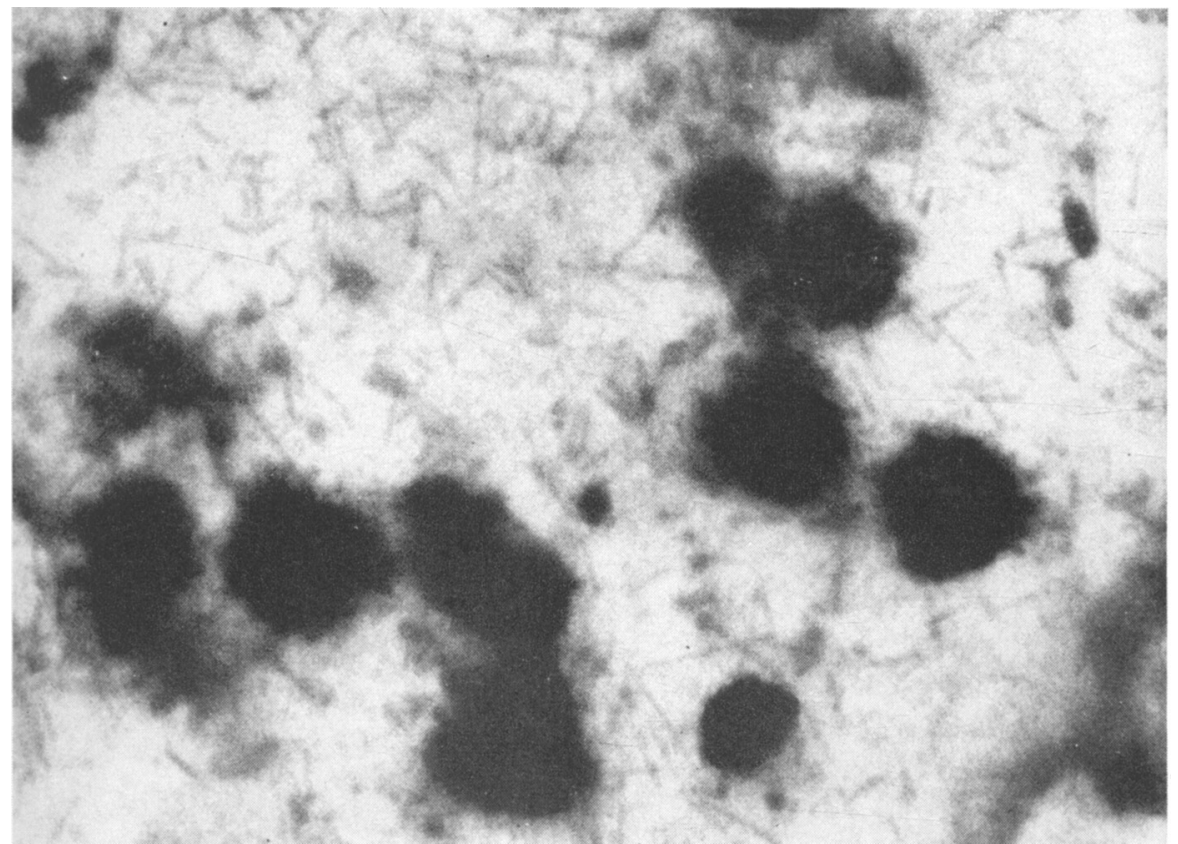

Fig. 14. A group of polyhedra somewhat more advanced than those shown in Fig. 13. Magnification 25,000 $\times$ 


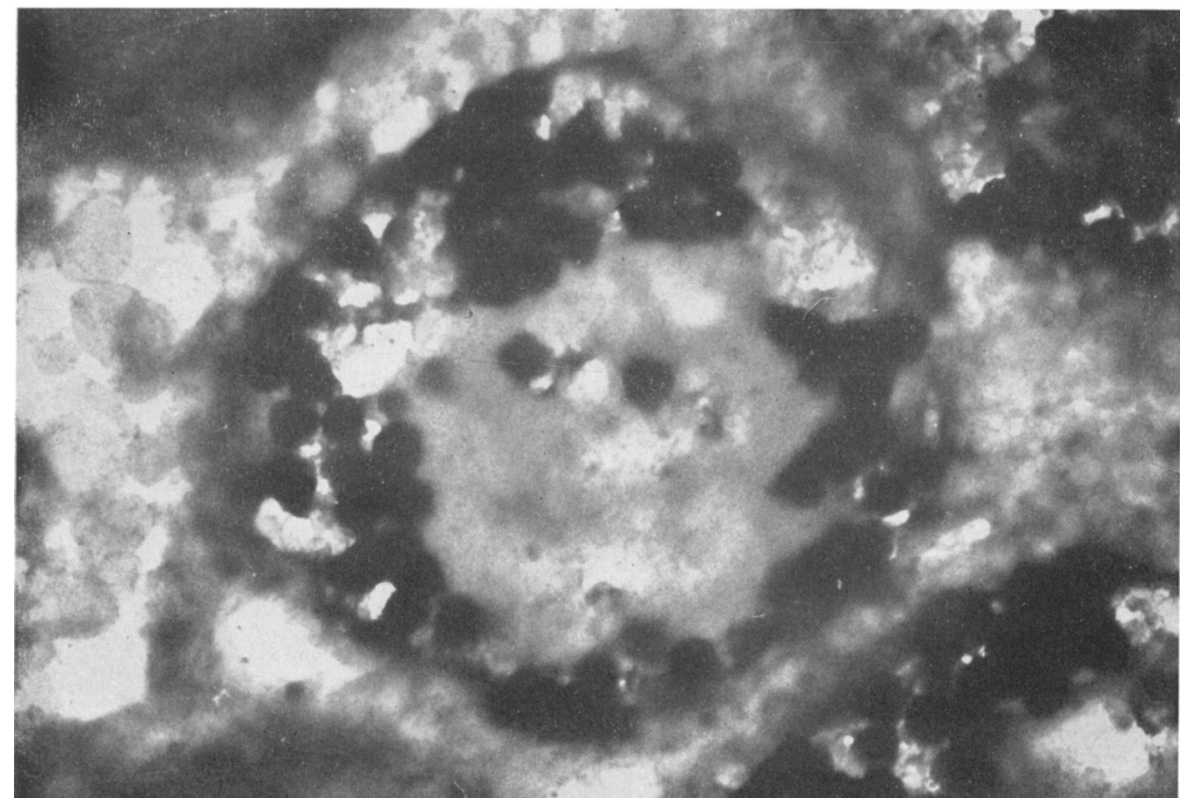

Fig. 15. Nucleus in an advanced stage of infection. This nucleus is smaller and the polyhedra less numerous than is usual at this stage of the disease. Magnification $7,000 \times$

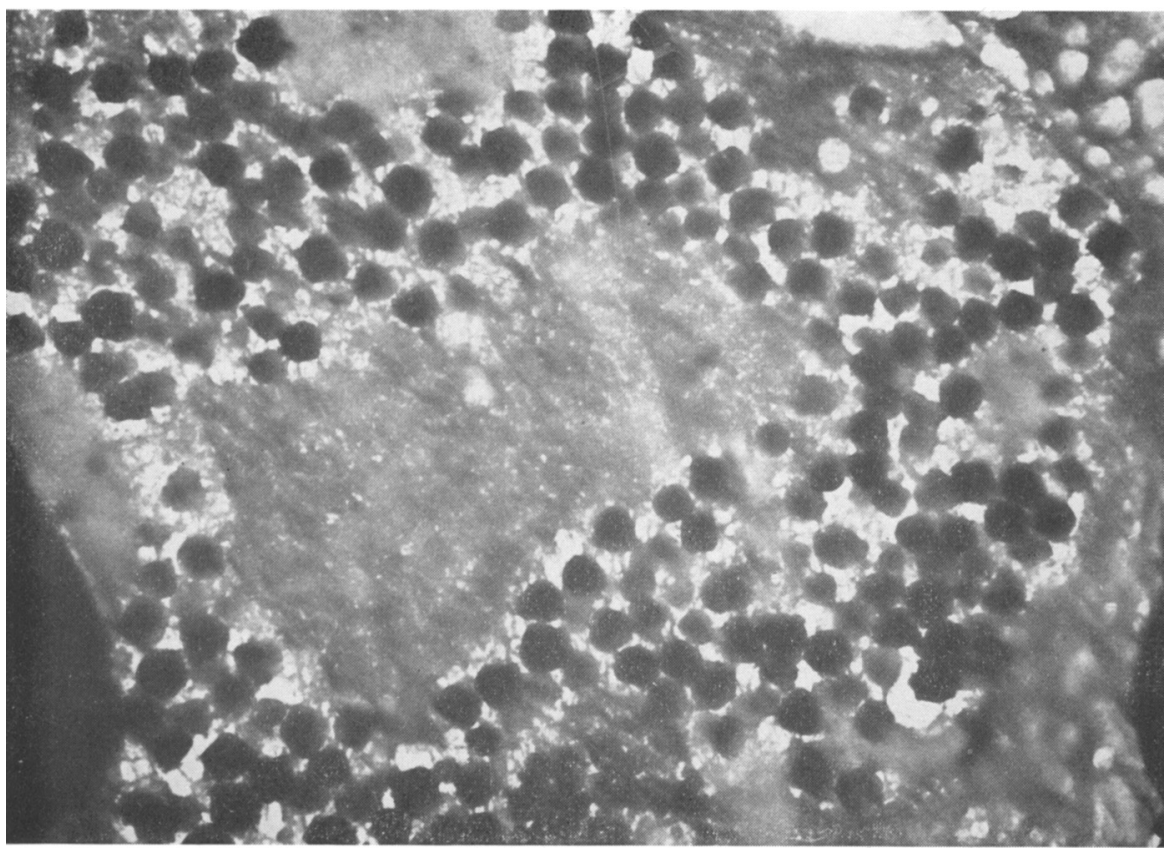

Fig. 16. Nucleus typical of those at a fairly advanced stage of infection. The polyhedra may become still larger and fill a greater proportion of the nucleus. Magnification 5,300 $\times$ 
versations, Dr. Bird pointed out the nucleus represented in figure 1 as typical of those he studied.

Bird's conclusions relative to the development of the polyhedra do not appear to be supported by the present work. He extracted the contents of nuclei and found what he believed to be voung polyhedra containing small spherical particles. The minute spheres, measuring about 20 millimicrons in diameter, "increase in size and number as the polyhedra increase in size." Bird suggests that these spheres may be elementary particles of the virus and implies that they develop into rods within the growing polyhedron.

In some respects the "immature polyhedra" described by Bird appear to be similar to the oroid bodies shown in figure 8 . However, the latter seem to arise as bundles of rods surrounded by a membrane whereas in the former no rod-shaped particles could be seen. Furthermore, the diameter of the smaller "polyhedra" described by Bird is given as about 160 millimicrons while the length of the virus rods is 250 millimicrons. Thus it would be impossible for some of the small "polyhedra" to contain rods in the same manner as do the bodies in figures 7 and 8 . Somewhat smaller opaque bodies were sometimes seen in these sections. While they could be similar to the bodies described by Bird, it is just as reasonable that they represent crosssections of the ovoid structures already described.

There is, of course, the possibility that both rods and spheres occur in the nucleus at the time of polyhedral body formation, that polyhedra may develop around either form of the virus, and that small polyhedra containing spherical forms of the virus escaped detection in the present work. That spherical forms of those insect viruses which usually are seen as rods do exist at some time in the development of the virus seems to be well established. Bergold (1950) found evidence for the existence of a developmental cycle which included spherical stages. Smith and Wyckoff $(1950,1951)$ and Bergold (1953) have demonstrated polyhedra-like structures containing spherical particles although it is not entirely clear whether these are viral in nature.

The present work throws very little light on the nature of spherical forms and, in fact, presents little evidence of their existence. Figure 3 shows some round dots which could be assumed to be early stages of the virus. One must keep in mind, however, the fact that the pictures presented here were made from sections and, hence, that cross-sections of rods will have a similar appearance. A little evidence to support the view that these round bodies may be an early stage of the virus might be derived from their appearance in greater number in earlier stages of infection than in later stages. It is not unlikely that the poor resolution obtainable in the electron microseopy of sections will not permit adequate determination of the identity of the apparent round particles seen here.

In attempting to relate Bird's conception of the origin of polyhedra with that presented above, it should be considered that there may be good reason for the existence of certain discrepancies. The virus studied by Bird affects a sawfly, Gilpinia hercyniae (Htg.) while the present work was based on a virus affecting one of the Lepidoptera. The fact that hosts in two different orders of insects are involved may be significant. Furthermore, the several 
sawfly viruses multiply in the nuclei of the midgut epithelium only, whereas, in the Lepidoptera, the gut epithelium seems to be singularly free of direct infection, the nuclear viruses multiplying in such tissues as fat, hypodermis, and blood cells. Since there are such significant differences ketween these two groups of viruses it might be quite erroneous to assume that the two are similar in all other respects.

Similarity to Some of Bergold's Results. What appear to be membranes surrounding virus particles in figure 7 are probably the same as structures described by Bergold (1950, 1953). Some of his figures (Bergold, 1950; see figures 38 and 44) bear a very strong resemblance to those presented here. He apparently considers these structures to represent an intermediate stage in the development of the virus particles, while in the present study they appear to be the final stage in such a process.

Tokuyasu's Findings. A recent paper by Tokuyasu (1953) presents some information that has a bearing on this discussion. After dissolving silkworm polyhedra, Tokuyasu found the virus particles to be encased in thick-walled envelopes. These structures could be identical with those shown in figure 8 . Tokuyasu noted the superficial similarity to the inclusion bodies of the granulosis viruses-a similarity strengthened in the instance he described by the fact that single rods seem to occur more frequently in silkworm polyhedra than do bundles.

Tokurasu's theory that virus particles occur predominantly in the outer layers of polyhedra seems to gain little support from the present work. His point of view is based on the assumptions that (1) the polyhedral protein is a product of the "metabolism" of virus multiplication and that (2) viral development progresses at a uniform rate and ceases at about the same time for all particles within an infected nucleus. Thus he feels that most of the polyhedral protein would already have been formed by the time the virus particles were at a stage at which they would be incorporated into the polyhedron. His conclusion is, then, that most of the particles must be near the surface of the polyhedron. There seems to be no evidence in the present work to support this viewpoint.

Recent Work of Smith and Xeros. At the time this manuscript was being. prepared for publication a note by Smith and Xeros (1953) appeared describing a similar study on the polyhedrosis of the silkworm. These workers believe the virus to arise from a "nuclear net"-a structure that is undoubtedly identical with the central chromatin mass described above. They believe that the chromatin mass has a fibrillar structure and that "these fibrils seem to thicken to the normal diameter of the virus."

This concept does not seem to coincide with the work presented here and contrasts strongly with the developmental cycle published by Bergold (1950). Figure 3 of the present work shows little evidence of a fibrillar structure of the chromatin network. The illustrations published by Smith and Xeros likewise provide little evidence for this point of view. However, the sections photographed by the latter authors were apparently too thick to permit observation of much detail in the chromatin mass. 


\section{SUMMARY}

By means of electron microscopy of thin sections, stages in the development of an insect virus within the host cells are shown in this study. The virus concerned is Borrelina campeoles Steinhaus, a polyhedrosis affecting the alfalfa caterpillar Colias philodice eurytheme Bdvl.

Rod-shaped virus particles appear in large numbers in the nucleus of an infected cell. The rods form bundles of two or more members, apparently surrounded by a membrane. A dense substance appearing within the membrane renders that structure opaque. Deposition of polyhedral protein around and between a number of bundles results in the formation of a small polyhedron containing bundles of virus particles. The polyhedron apparently grows by the progressive deposition of polyhedral protein at its periphery and the entrapping of adjacent bundles within its mass. The relationships of these findings to those of other authors is discussed.

\section{ACKNOWLEDGMENT}

The writer wishes to acknowledge the assistance of Mrs. Marjorie Glathe I)inkins, whose technical skill and patience in the preparation of sections contributed greatly to this study.

\section{LITERATURE CITED}

Bergold, G. H.

1947. Die Isolierung des Polyeder-Virus und die Natur der Polyeder. Z. Naturforseh. $2 \mathrm{~b}: 122-43$

1950. The multiplication of insect viruses as organisms. Canadian Jour. Res. $28: 5-11$.

1953. On the nomenclature and classification of insect viruses. Ann. New York Acad. Sci. $56: 495-516$.

BIRD, F. T.

1952. On the multiplication of an insect virus. Biochim. Biophys. Acta 8:360-68.

Breinde, V., and J. Komárek.

1923. Zur Aetiologie der Wipfelkrankheit (Polyedrie) der Nonne (Lymantria monacha). Věstník Královské Ceské Společnosti Nauk, třída matematickopř́rodovědecká. (Mém. Soc. Roy. Sci. Bohême, classe des sciences), 1921-1922, $20 \mathrm{pp}$.

Hughes, K. M.

1950. A demonstration of the nature of polyhedra using alkaline solutions. Jour. Bact. $59: 189-95$.

Newman, S. B., E. Borysko, and M. Swerdlow.

1949. New sectioning techniques for light and electron microscopy. Science 110:66-68.

Paillot, A.

1924. Sur l'étiologie et l'épidémiologie de la "grasserie" du ver à soie. Compt. rend. Acad. Sci. $179: 229-31$.

Pease, D. C., and R. F. BaKer.

1948. Sectioning techniques for electron microscopy using a conventional microtome. Proc. Soc. Exp. Biol. and Med. 67:47()-74.

Sмiтh, K. M., and R. W. G. Wyскоғғ.

1950. Structure within polyhedra associated with insect virus diseases. Nature 166:861.

1951. Electron microscopy of insect viruses. Research $4: 148-55$. 
SMITH, K. M., and N. Xeros.

1953. Development of virus in the cell nucleus. Nature 172:670-71.

Steinhaus, E. A.

1948. Polyhedrosis ("wilt disease") of the alfalfa caterpillar. Jour. Econ. Ent. 41:85965.

1949a. Nomenclature and classification of insect viruses. Bact. Rev. 3:203-23.

1949b. Principles of insect pathology. McGraw-IHill Book Co., New York. 757 pp. TokUyasu, $\mathrm{K}$.

1953. The structures and development of silkworm polyhedra. Enzymologia 16:62-68. 
The journal Hilgardia is published at irregular intervals, in volumes of about 600 pages. The number of issues per volume varies.

Subscriptions are not sold. The periodical is sent as published only to libraries, or to institutions in foreign countries having publications to offer in exchange.

You may obtain a single copy of any issue free, as long as the supply lasts; please request by volume and issue number from:

\section{Publications Office \\ College of Agriculture \\ Berkeley 4, California}

The limit to nonresidents of California is 10 separate issues on a single order. A list of the issues still available will be sent on request. 